\title{
Cytotoxic and Antibacterial Compounds from the Coral-Derived Fungus Aspergillus tritici SP2-8-1
}

\author{
Weiyi Wang $1,2,3,+$, Yanyan Liao ${ }^{1,2,4,+}$, Chao Tang ${ }^{1,2,4}$, Xiaomei Huang ${ }^{1,2,4}$, Zhuhua Luo ${ }^{3}$, \\ Jianming Chen ${ }^{3,5, *}$ and Peng Cai ${ }^{1,2,4, *}$ \\ 1 Key Laboratory of Urban Environment and Health, Institute of Urban Environment, Chinese Academy \\ of Sciences, Xiamen 361021, China; wywang@iue.ac.cn (W.W.); yyliao@iue.ac.cn (Y.L.); \\ ctang@iue.ac.cn (C.T.); xmhuang@iue.ac.cn (X.H.) \\ 2 University of Chinese Academy of Sciences, Beijing 100049, China \\ 3 State Key Laboratory Breeding Base of Marine Genetic Resources, Key Laboratory of Marine \\ Genetic Resources, Fujian Key Laboratory of Marine Genetic Resources, Fujian Collaborative Innovation \\ Centre for Exploitation and Utilization of Marine Biological Resources, Third Institute of Oceanography, \\ State Oceanic Administration, Xiamen 361005, China; luozh_fj@163.com \\ 4 Xiamen Key Laboratory of Physical Environment, Xiamen 361021, China \\ 5 Institute of Oceanography, Minjiang University, Fuzhou 350108, China \\ * Correspondence: chenjianming@tio.org.cn (J.C.); pcai@iue.ac.cn (P.C.); Tel.: +86-592-219-5518 (J.C.); \\ +86-592-619-0568 (P.C.) \\ + These authors contributed equally to this work.
}

Received: 1 September 2017; Accepted: 3 November 2017; Published: 7 November 2017

\begin{abstract}
Three novel compounds, 4-methyl-candidusin A (1), aspetritone A (2) and aspetritone B (3), were obtained from the culture of a coral-derived fungus Aspergillus tritici SP2-8-1, together with fifteen known compounds (4-18). Their structures, including absolute configurations, were assigned based on NMR, MS, and time-dependent density functional theory (TD-DFT) ECD calculations. Compounds 2 and 5 exhibited better activities against methicillin-resistant strains of $S$. aureus (MRSA) ATCC 43300 and MRSA CGMCC 1.12409 than the positive control chloramphenicol. Compound 5 displayed stronger anti-MRSA and lower cytotoxic activities than 2, and showed stronger antibacterial activities against strains of Vibrio vulnificus, Vibrio rotiferianus, and Vibrio campbellii than the other compounds. Compounds $\mathbf{2}$ and $\mathbf{1 0}$ exhibited significantly stronger cytotoxic activities against human cancer cell lines HeLa, A549, and Hep G2 than the other compounds. Preliminary structure-activity relationship studies indicated that prenylation of terphenyllin or candidusin and the tetrahydrobenzene moiety in anthraquinone derivatives may influence their bioactivity.
\end{abstract}

Keywords: Aspergillus; candidusin; aspetritone; cytotoxic; antibacterial

\section{Introduction}

To date, approximately 70,000 species of fungi have been characterized [1]. Among them, about 1500 species of marine-derived fungi were mentioned, mainly from coastal ecosystems [1]. In recent years, the fungal sources of novel metabolites have broadened from saprophytic terrestrial strains to marine habitats and living plants with their endophytes [2]. Specifically, metabolites isolated from species of the genus Aspergillus have continually attracted the interest of pharmacologists due to their broad array of biological activities and their structural diversity. A. tritici, A. campestris, A. taichungensis, and A. candidus, which are members of the Aspergillus section Candidi, are known to be the prolific producers of bioactive secondary metabolites, including terphenyllin, candidusins, and anthraquinones [3]. 
As part of our ongoing efforts to discover bioactive compounds from coral-derived microorganisms, an Aspergillus tritici strain, SP2-8-1, isolated from the coral of Galaxea fascicularis, collected at Port Dickson, Malaysia, attracted our attention. Studies on the bioactive constituents of its extract led to the isolation of three novel compounds, 4-methyl-candidusin A (1), aspetritone A (2) and aspetritone $B(3)$, together with fifteen known analogues, including prenylcandidusin derivatives (4-5), candidusin derivatives (6-7), terphenyllin derivatives (8-14), and anthraquinone derivatives (15-18) (Figure 1).

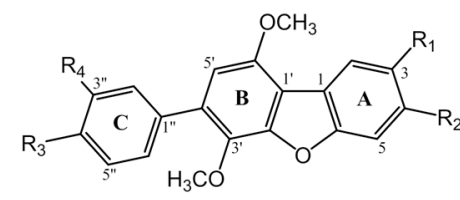

1: $\mathrm{R}_{1}=\mathrm{R}_{3}=\mathrm{OH} \mathrm{R}_{2}=\mathrm{OCH}_{3} \mathrm{R}_{4}=\mathrm{H}$
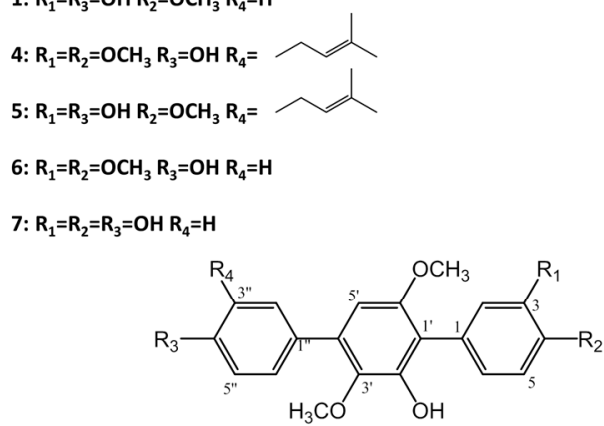

8: $R_{1}=R_{2}=R_{3}=R_{4}=H$

9: $R_{1}=R_{3}=R_{4}=H ~ R_{2}=O H$

10: $R_{1}=R_{2}=R_{3}=O H R_{4}=H$

11: $R_{1}=R_{4}=H \quad R_{2}=R_{3}=O H$

12: $R_{1}=R_{2}=R_{3}=O H ~ R_{4}=H$

13: $\mathrm{R}_{1}=\mathrm{R}_{2}=\mathrm{OH} \mathrm{R} \mathrm{R}_{3}=\mathrm{R}_{4}=\mathrm{H}$

14: $R_{1}=H R_{2}=R_{3}=\mathrm{OH} \mathrm{R} R_{4}=$<smiles>COC1=C(OC)C(O)c2cc3c(c(O)c2C1=O)CC(C)C(O)C3O</smiles>

2<smiles>COC1C(=O)CC(O)C2C(=O)C3=C(O)C(=C(O)C12)C(O)C(O)C(C)(O)C3</smiles>

bostrycin<smiles>COc1cc(OC)c2c(c1O)C(=O)C1=C(CC(O)C(C)(O)C1)C2=O</smiles>

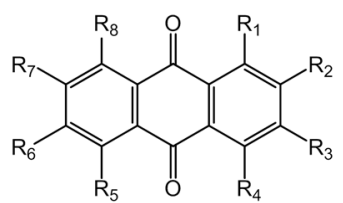

15: $R_{1}=R_{3}=R_{6}=R_{8}=H \quad R_{2}=R_{4}=R_{5}=O H \quad R_{7}=C_{3}$

16: $R_{1}=R_{2}=R_{5}=R_{6}=O H_{3} R_{3}=O H R_{4}=R_{7}=R_{8}=H$

17: $\mathrm{R}_{1}=\mathrm{OCH}_{3} \mathrm{R}_{2}=\mathrm{CH}_{2} \mathrm{OH} \mathrm{R}_{3}=\mathrm{OH} \mathrm{R}_{4}=\mathrm{R}_{5}=\mathrm{R}_{6}=\mathrm{R}_{7}=\mathrm{R}_{8}=\mathrm{H}$

18: $R_{1}=R_{2}=R_{3}=O C_{3} R_{4}=R_{5}=R_{6}=R_{8}=H R_{7}=\mathrm{CH}_{2} O H$

Figure 1. Structure of compounds 1-18.

\section{Results and Discussion}

4-methyl-candidusin A (1) was obtained as a colorless amorphous solid. Its molecular formula was established as $\mathrm{C}_{21} \mathrm{H}_{18} \mathrm{O}_{6}$ by high-resolution electrospray ionization mass spectroscopy (HR-ESI-MS) $\left(m / z 367.11757[\mathrm{M}+\mathrm{H}]^{+}\right.$; calcd for $\left.\mathrm{C}_{21} \mathrm{H}_{19} \mathrm{O}_{6}, 367.11816\right)$, implying 13 degrees of unsaturation. The ${ }^{13} \mathrm{C} /$ distortionless enhancement by polarization transfer (DEPT) spectrum showed resonances for three methoxyl, seven methine, and 11 quaternary carbons. The ${ }^{1} \mathrm{H}$ NMR spectrum displayed an $\mathrm{AB}$ system at $\delta_{H}\left[6.85\left(\mathrm{~d}, J=8.53, \mathrm{H}-3^{\prime \prime}, 5^{\prime \prime}\right)\right.$ and $\left.7.42\left(\mathrm{~d}, J=8.53, \mathrm{H}-2^{\prime \prime}, 66^{\prime \prime}\right)\right]$; three aromatic singlets at $\delta_{H}[7.39(\mathrm{~s}, \mathrm{H}-2)], \delta_{H}[7.38(\mathrm{~s}, \mathrm{H}-5)]$, and $\delta_{H}\left[6.72\left(\mathrm{~s}, \mathrm{H}-5^{\prime}\right)\right]$; three methoxyl singlets at $\delta_{H}\left[3.87\left(\mathrm{~s}, \mathrm{OCH}_{3}-4\right)\right], \delta_{H}\left[3.77\left(\mathrm{~s}, \mathrm{OCH}_{3}-3^{\prime}\right)\right]$, and $\delta_{H}\left[3.97\left(\mathrm{~s}, \mathrm{OCH}_{3}-6^{\prime}\right)\right] ;$ and two phenolic $\mathrm{OH}$ groups at $\delta_{H}\left[9.06\right.$ (brs, OH-3)] and $\delta_{H}[9.55$ (brs, OH-4")] (Table 1). In comparison with the previously reported candidusin A [4], the lack of a phenolic $\mathrm{OH}$ unit and the appearance of a methoxyl group in 1 were observed, confirmed by evidence of a 14 amu increase in the molecular weight of $\mathbf{1}$. In addition, they shared the same substructures of rings $B$ and $C$, with the main differences located on ring $A$. In combining the correlations of ${ }^{1} \mathrm{H}-{ }^{1} \mathrm{H}$ COSY and heteronuclear multiple bond correlation (HMBC) spectra (Figure 2) with the "no splitting" of $\mathrm{H}-2$ and $\mathrm{H}-5$, we assigned the structure of compound $\mathbf{1}$ as 4-methyl-candidusin A (1). 


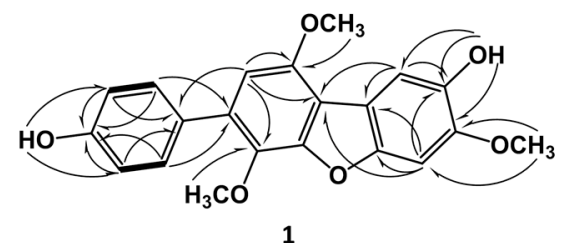

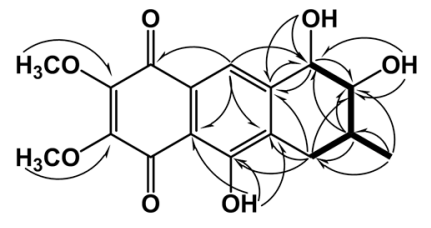

2

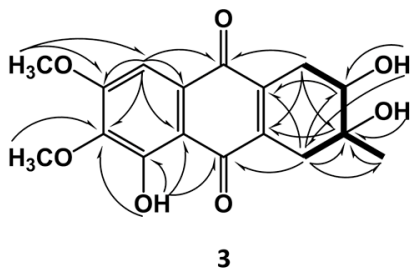

$\cos Y$

Figure 2. Key COSY and HMBC correlations of compounds 1-3.

Table 1. ${ }^{1} \mathrm{H}$ NMR data $(400 \mathrm{MHz})$ and ${ }^{13} \mathrm{C}$ NMR data $(100 \mathrm{MHz})$ for compounds $1-3$.

\begin{tabular}{|c|c|c|c|c|c|c|}
\hline \multirow{2}{*}{ Position } & \multicolumn{2}{|l|}{1} & \multicolumn{2}{|l|}{2} & \multicolumn{2}{|l|}{3} \\
\hline & $\delta_{\mathrm{H}}$, mult. $(J$ in $\mathrm{Hz})$ & $\delta_{C}$ & $\delta_{\mathrm{H}}$, mult. $(J$ in $\mathrm{Hz})$ & $\delta_{C}$ & $\delta_{\mathrm{H}}$, mult. $(J$ in $\mathrm{Hz})$ & $\delta_{C}$ \\
\hline 1 & & 114.9 & $4.26, \mathrm{~d}(7.03)$ & 73.8 & $\begin{array}{l}\text { 2.54, dd }(19.84,4.88) \text {, Heq } \\
\text { 2.69, dd (19.84, 11.63), Hax }\end{array}$ & 30.1 \\
\hline 2 & $7.39, \mathrm{~s}$ & 107.3 & $3.13, \mathrm{~m}$ & 76.3 & $3.59, \mathrm{~m}$ & 69.7 \\
\hline 3 & & 144.0 & $1.76, \mathrm{~m}$ & 33.5 & & 69.1 \\
\hline 4 & & 148.4 & $\begin{array}{l}2.19 \text {, dd }(18.45,11.46), \text { Hax } \\
2.92 \text {, dd }(18.45,5.40) \text {, Heq }\end{array}$ & 31.3 & 2.45, br d (13.30) & 33.0 \\
\hline 5 & $7.38, \mathrm{~s}$ & 96.6 & & 187.2 & & 155.1 \\
\hline 6 & & 149.7 & & 148.8 & & 140.8 \\
\hline 7 & & & & 146.9 & & 157.9 \\
\hline 8 & & & & 181.1 & $7.16, \mathrm{~s}$ & 104.0 \\
\hline 9 & & & $7.65, \mathrm{~s}$ & 118.1 & & 183.5 \\
\hline 10 & & & & 158.0 & & 189.2 \\
\hline 11 & & & & 111.0 & & 110.8 \\
\hline 12 & & & & 128.5 & & 127.9 \\
\hline 13 & & & & 148.6 & & 142.8 \\
\hline 14 & & & & 131.7 & & 142.6 \\
\hline $1^{\prime}$ & & 114.2 & & & & \\
\hline $2^{\prime}$ & & 149.0 & & & & \\
\hline $3^{\prime}$ & & 136.4 & & & & \\
\hline $4^{\prime}$ & & 131.4 & & & & \\
\hline $5^{\prime}$ & $6.72, \mathrm{~s}$ & 106.0 & & & & \\
\hline $6^{\prime}$ & & 150.0 & & & & \\
\hline $1^{\prime \prime}$ & & 129.0 & & & & \\
\hline $2^{\prime \prime}, 6^{\prime \prime}$ & $7.42, \mathrm{~d}(8.53)$ & 130.8 & & & & \\
\hline $3^{\prime \prime}, 5^{\prime \prime}$ & $6.85, \mathrm{~d}(8.53)$ & 115.5 & & & & \\
\hline $4^{\prime \prime}$ & & 157.2 & & & & \\
\hline $\mathrm{CH}_{3}-3$ & & & $1.08, \mathrm{~d}(6.53)$ & 18.5 & $1.21, \mathrm{~s}$ & 26.0 \\
\hline $\mathrm{OCH}_{3}-4$ & $3.87, \mathrm{~s}$ & 56.4 & & & & \\
\hline $\mathrm{OCH}_{3}-6$ & & & $3.99, \mathrm{~s}$ & 61.4 & $3.79, \mathrm{~s}$ & 60.8 \\
\hline $\mathrm{OCH}_{3}-7$ & & & $3.95, \mathrm{~s}$ & 61.7 & $3.92, \mathrm{~s}$ & 56.8 \\
\hline $\mathrm{OCH}_{3}-3^{\prime}$ & $3.77, \mathrm{~s}$ & 61.0 & & & & \\
\hline $\mathrm{OCH}_{3}-6^{\prime}$ & $3.97, \mathrm{~s}$ & 56.3 & & & & \\
\hline $\mathrm{OH}-1$ & & & $5.82, \mathrm{~d}(6.27)$ & & & \\
\hline $\mathrm{OH}-2$ & & & $5.06, \mathrm{~d}(5.02)$ & & 4.73, br s & \\
\hline $\mathrm{OH}-3$ & 9.06 , brs & & & & 5.03 , br s & \\
\hline $\mathrm{OH}-5$ & & & & & $12.09, \mathrm{~s}$ & \\
\hline $\mathrm{OH}-10$ & & & $12.18, \mathrm{~s}$ & & & \\
\hline $\mathrm{OH}-4^{\prime \prime}$ & 9.55 , brs & & & & & \\
\hline
\end{tabular}

Aspetritone A (2) was obtained as a yellow amorphous solid. Its molecular formula was established as $\mathrm{C}_{17} \mathrm{H}_{18} \mathrm{O}_{7}$ by HRESIMS $\left(m / z 333.0966[\mathrm{M}-\mathrm{H}]^{-}\right.$; calcd. for $\left.\mathrm{C}_{17} \mathrm{H}_{17} \mathrm{O}_{7}, 333.0974\right)$, 
implying nine degrees of unsaturation. The ${ }^{13} \mathrm{C}$ NMR spectrum showed resonances for two methoxyl, one methyl, one methylene, four methine, and nine quaternary carbons. The ${ }^{1} \mathrm{H}$ NMR spectrum displayed an aromatic proton $\delta_{H}[7.65(\mathrm{~s}, \mathrm{H}-9)]$, and two methoxyls at $\delta_{H}\left[3.99\left(\mathrm{~s}, \mathrm{OCH}_{3}-6\right)\right]$ and $\delta_{H}$ [3.95 (s, $\left.\left.\mathrm{OCH}_{3}-7\right)\right]$. In comparison with the published data on bostrycin $[5,6]$, both the ${ }^{1} \mathrm{H}$ NMR and ${ }^{13} \mathrm{C}$ NMR were similar, suggesting that compound 2 was a bostrycin derivative. Analysis of $1 \mathrm{D}$ NMR, ${ }^{1} \mathrm{H}-{ }^{1} \mathrm{H}$ COSY, heteronuclear single quantum correlation (HSQC), and HMBC data revealed the presence of one 1,2-dihydroxy-3-methylbutane unit and one pentasubstituted naphthoquinone moiety. In the HMBC spectrum, correlations of $\mathrm{H}-1$ with $\mathrm{C}-9$ and $\mathrm{C}-13$, and of $\mathrm{H}-4$ with $\mathrm{C}-10$ and $\mathrm{C}-14$, indicated 1,2-dihydroxy-3-methylbutane was connected to the naphthoquinone by linkage of C-1 with $\mathrm{C}-13$ and of $\mathrm{C}-4$ with $\mathrm{C}-14$ (Figure 2). The phenolic $\mathrm{OH}$ was attached to $\mathrm{C}-10$ by HMBC correlations of $\delta_{H}[12.18(\mathrm{~s}, \mathrm{OH}-10)]$ with $\mathrm{C}-10, \mathrm{C}-11$, and C-14. The aromatic proton $\delta_{H}[7.65$ (s, H-9)] showed HMBC correlations with C-1, C-8, C-11, and C-14, suggesting C-9 was unsubstituted and the two methoxy groups were attached to C-6 and C-7. Therefore, the planar structure of compound 2 was identified as 3, 9-deoxy-7-methoxybostrycin and named aspetritone A (2).

The relative configuration of 2 was elucidated based on NOESY spectra (Figure 3). The strong NOESY correlations of $\mathrm{H}-1$ with $\mathrm{H}-3$ and of $\mathrm{H}-2$ with $\mathrm{H}_{\mathrm{ax}}-4$ indicated that both $\mathrm{H}-1$ and $\mathrm{H}-3$ faced to the same side of the tetrahydrobenzene ring and $\mathrm{H}-2$ oriented to the opposite side. Therefore, two possible isomers of $(1 S, 2 S, 3 R)-2$ and $(1 R, 2 R, 3 S)-2$ were proposed, and their ECD spectra were calculated by time-dependent density functional theory (TD-DFT). The experimental ECD spectrum of 2 was in good agreement with the calculated ECD spectrum of $(1 S, 2 S, 3 R)-2$ (Figure 4), and the axial-axial coupling constants of ${ }^{3} J_{\mathrm{Hax}-1, \mathrm{H}-2}(7.03)$ and ${ }^{3} J_{\mathrm{Hax}-3, \mathrm{Hax}-4}(11.46)$ indicated a half-chair form of the tetrahydrobenzene ring with all of $\mathrm{OH}-1, \mathrm{OH}-2$, and $\mathrm{CH}_{3}-3$ in equatorial positions. In combining the NOESY correlations with the proton coupling constants, the absolute configuration of 2 was established as $(1 S, 2 S, 3 R)-3$, 9-deoxy-7-methoxybostrycin (2).

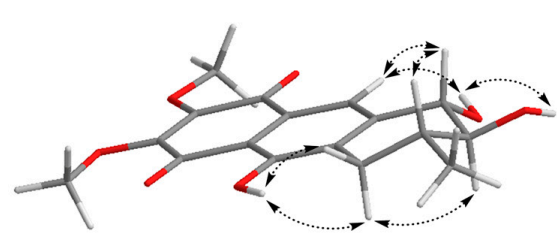

2

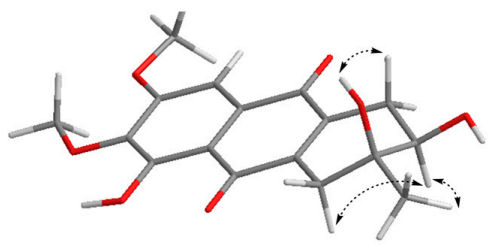

3

\section{A NOESY}

Figure 3. Key NOESY correlations of compounds 2 and 3.
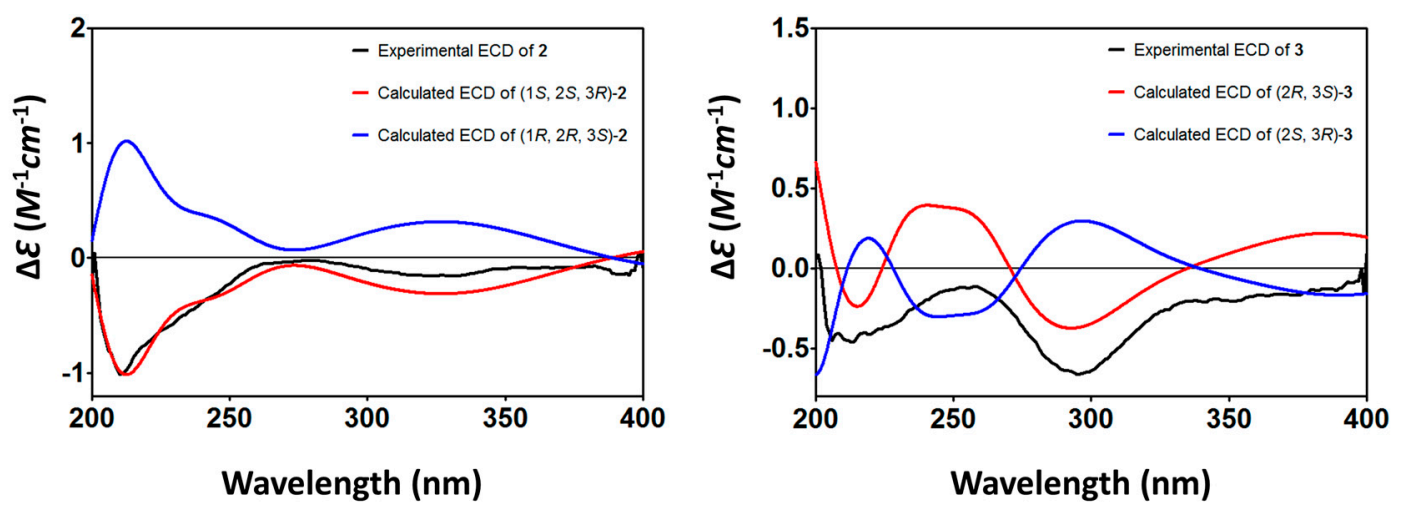

Figure 4. Calculated and Experimental ECD of compounds 2 and 3.

Aspetritone B (3) was obtained as a yellow amorphous solid, and its molecular formula was determined as $\mathrm{C}_{17} \mathrm{H}_{18} \mathrm{O}_{7}$ by HRESIMS $\left(m / z 333.0979[\mathrm{M}-\mathrm{H}]^{-}\right.$; calcd. for $\mathrm{C}_{17} \mathrm{H}_{17} \mathrm{O}_{7}$, 
333.0974), implying nine degrees of unsaturation. The ${ }^{13} \mathrm{C}$ NMR spectrum showed resonances for two methoxyl, one methyl, two methylene, two methine, and ten quaternary carbons. The ${ }^{1} \mathrm{H}$ NMR spectrum displayed an aromatic proton $\delta_{H}[7.16(\mathrm{~s}, \mathrm{H}-8)]$, and two methoxyls at $\delta_{H}\left[3.79\left(\mathrm{~s}, \mathrm{OCH}_{3}-6\right)\right]$ and $\delta_{H}\left[3.92\left(\mathrm{~s}, \mathrm{OCH}_{3}-7\right)\right]$. In comparison with the published data of prisconnatanone A [7-9], both the ${ }^{1} \mathrm{H}$ NMR and ${ }^{13} \mathrm{C}$ NMR were similar, suggesting that compound 2 was a tetrahydroanthraquinone derivative. Analysis of $1 \mathrm{D}$ NMR, ${ }^{1} \mathrm{H}-{ }^{1} \mathrm{H}$ COSY, HSQC, and HMBC data revealed the presence of one 2,3-dihydroxy-3-methylbutane unit and one pentasubstituted naphthoquinone moiety. In HMBC spectra, correlations of $\mathrm{H}-1$ with C-9 and C-14, and H-4 with C-10 and C-13, indicated that 2,3-dihydroxy-3-methylbutane was connected to the naphthoquinone by linkage of C-1 with C-13 and of C-4 with C-14. The phenolic $\mathrm{OH}$ was attached to $\mathrm{C}-5$ by HMBC correlations of $\delta_{H}[12.09$ (s, OH-5)] with C-5, C-6, and C-11. The aromatic proton $\delta_{H}$ [7.16 (s, H-8)] showed HMBC correlations with C-6, C-7, C-9, C-11, and C-12, suggesting C-8 was unsubstituted and the two methoxy groups were attached to C-6 and C-7 (Figure 2). Therefore, the planar structure of compound 3 was assigned as 1,2,3,4-tetrahydro-2,3,5-trihydroxy-3-methyl-6,7-dimethoxyanthracene-9,10-dione and named aspetritone B (3).

The relative configuration of 3 was elucidated based on NOESY spectra (Figure 3). The strong NOESY correlations of $\mathrm{H}_{\mathrm{ax}}-1$ with $\mathrm{OH}-3$ and of $\mathrm{H}-2$ with $\mathrm{CH}_{3}-3$ indicated cis-configuration of $\mathrm{OH}-2$ and OH-3. Therefore, two possible isomers of $(2 R, 3 S)-3$ and $(2 S, 3 R)-3$ were proposed, and their ECD spectra were calculated by TD-DFT. The experimental ECD spectrum of 3 was in good agreement with the calculated ECD spectrum of $(2 R, 3 S)-3$ (Figure 4$)$, and the axial-axial coupling constants of ${ }^{3} \mathrm{~J}_{\mathrm{Hax}-1, \mathrm{H}-2}$ (11.63) indicated a half-chair form of the tetrahydrobenzene ring with $\mathrm{OH}-2$ and $\mathrm{CH}_{3}-3$ in equatorial positions. In combining the NOESY correlations with the proton coupling constants, the absolute configuration of $\mathbf{3}$ was established as (2R, 3S)-1,2,3,4-tetrahydro-2,3,5-trihydroxy-3-methyl-6,7-dimethoxyanthracene-9,10-dione (3).

The known compounds (4-18) were identified as 3,4-dimethyl-3"-prenylcandidusin A (4) [3], 4-methyl-3"-prenylcandidusin A (5) [3], 3,4-dimethyl-candidusin A (6) [3], candidusin A (7) [3], 4,4'-deoxy-terphenyllin (8) [10,11], 4"-deoxyterphenyllin (9) $[10,11]$, 3-prenylterphenyllin (10) [10,11], terphenyllin (11) [12], 3-hydroxyterphenyllin (12) [13], 3-hydroxy-4"-deoxyterphenyllin (13) [11,14], 3"-prenylterphenyllin (14) [15], emodin (15) [16], 3-hydroxy- 1,2,5,6-tetramethoxyanthracene-9,10-dione (16) [16], 3-hydroxy-2-hydroxymethyl-1-methoxyanthracene-9,10-dione (17) [16], and 1,2,3-trimethoxy-7-hydroxymethylanthracene-9,10-dione (18) [16] respectively, by comparing their spectroscopic data with those reported in the literature.

The cytotoxic and antimicrobial activity of compounds 1-18 was evaluated using cell lines of HeLa, A549, and Hep G2, and strains of methicillin-resistant Staphylococcus aureus (MRSA) (ATCC 43300, CGMCC 1.12409), Vibrio vulnificus MCCC E1758, Vibrio rotiferianus MCCC E385, and Vibrio campbellii MCCC E333 (Table 2). In comparison to the positive control chloramphenicol, for strains of MRSA, compounds 2 and 5 exhibited better antibacterial activities, and compounds 1, 3, 4, 7, 9-12, and 14-16 showed weaker activities. Compound $\mathbf{5}$ displayed stronger anti-MRSA and lower cytotoxic activities than compound 2. For strains of Vibrio, compound $\mathbf{5}$ showed stronger antibacterial activities than the other compounds, with MIC values ranging from 7-15 $\mu \mathrm{g} / \mathrm{mL}$. For cytotoxicity, compounds 2 and 10 showed significantly stronger activities than the other compounds with $\mathrm{IC}_{50}$ values below $5 \mu \mathrm{M}$. 
Table 2. Antibacterial and cytotoxic activities of compounds 1-18. Data are expressed as mean \pm SD values of three independent experiments, each made in triplicate.

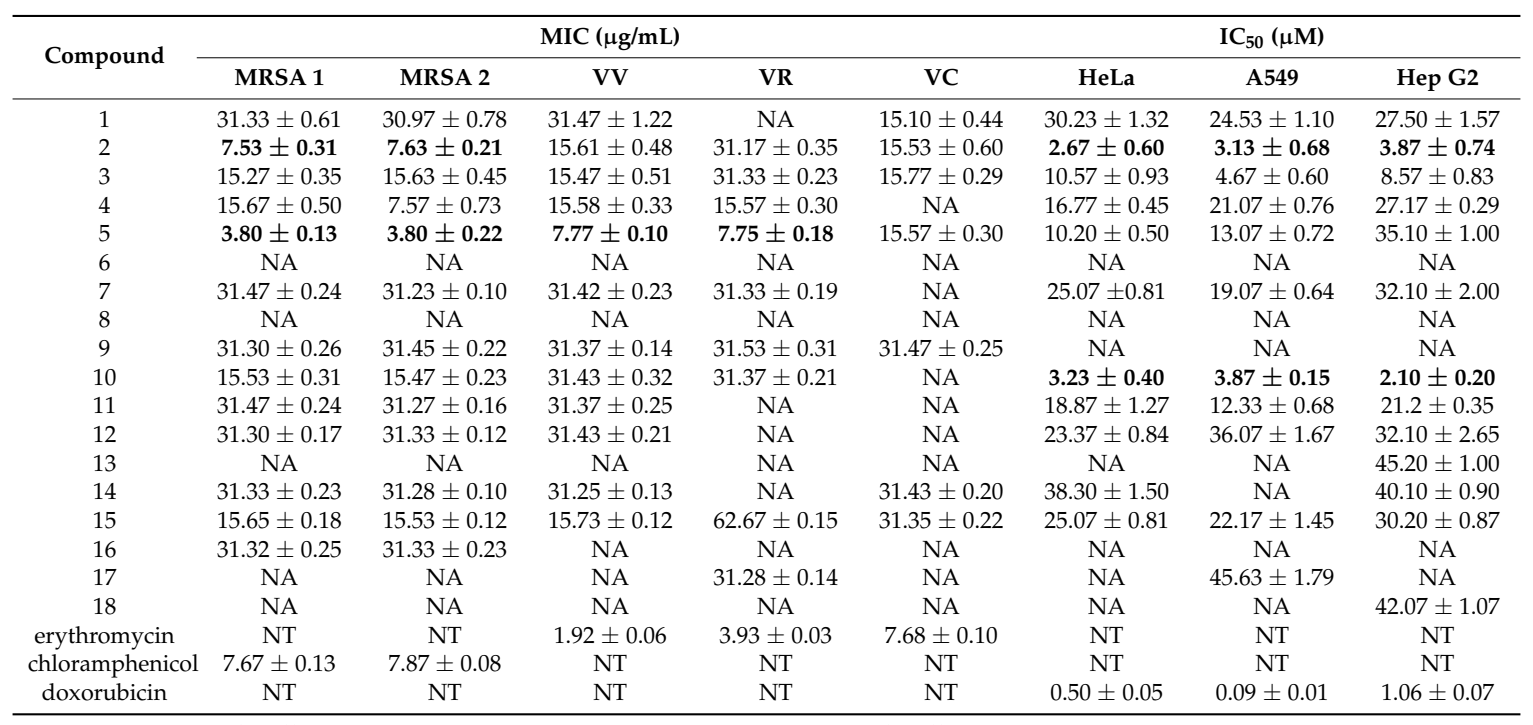

MRSA 1: methicillin-resistant S. aureus ATCC 43300; MRSA 2: methicillin-resistant S. aureus CGMCC 1.12409; VV: V. vulnificus MCCC E1758; VR: V. rotiferianus MCCC E385; VC: V. campbellii MCCC E333; NA: no activity at the concentration of $50 \mu \mathrm{g} / \mathrm{mL}$ (antibacterial) or $50 \mu \mathrm{M}$ (cytotoxic); NT: not tested.

\section{Materials and Methods}

\subsection{General Experimental Procedures}

1D NMR and 2D NMR spectra were recorded on a Bruker DRX-400 instrument. HRESIMS was carried out on Bruker Daltonics Apex ultra 7.0 T Fourier transform mass spectrometer with an electrospray ionization source (Apollo II, Bruker Daltonics, Bremen, Germany). Optical rotations were measured with a P-1020 digital polarimeter (JASCO Corporation, Tokyo, Japan). CD spectra were measured on a J-715 spectropolarimeter (JASCO Corporation). The UV spectra were recorded on a UV-1800 spectrophotometer (Shimadzu, Japan). Thin-layer chromatography (TLC) plates $(5 \times 10 \mathrm{~cm}$ ) were performed on GF254 (Branch of Qingdao Marine Chemical Co. Ltd., Qingdao, China) plates. For column chromatography (CC), RP-C18 (ODS-A, $50 \mu \mathrm{m}, \mathrm{YMC}$, Kyoto, Japan), silica gel (200-300 mesh, 300-400 mesh, Branch of Qingdao Marine Chemical Co. Ltd., Qingdao, China), and Sephadex LH-20 (GE Healthcare Bio-Science AB, Pittsburgh, PA, USA) were used. The high performance liquid chromatography (HPLC) analysis was performed on a Waters 2695-2998 system (Waters, Milford, CT, USA). Semi-preparative HPLC was run with a P3000 pump (CXTH, Beijing, China) and a UV3000 ultraviolet-visible detector (CXTH, Beijing, China), using a preparative RP-C18 column $(5 \mu \mathrm{m}, 20 \times 250 \mathrm{~mm}$, YMC, Kyoto, Japan).

\subsection{Fungal Material}

Strain SP2-8-1 of A. tritici was isolated from the coral Galaxea fascicularis collected at Port Dickson, Malaysia, and was identified by ITS sequence homology (100\% similarity with A. tritici CBS 266.81 with Genbank Accession No. KP987088.1 (max score 972, e value 0.0, query cover 100\%)). The fungal strain was inoculated into a $15 \mathrm{~mL}$ centrifuge tube containing $3 \mathrm{~mL}$ of potato dextrose medium and cultured at $28^{\circ} \mathrm{C}$ at $150 \mathrm{rpm}$ for 3 days. Total genomic DNA was extracted as described by Lai et al. [17]. The internal transcribed spacer (ITS) region of rDNA was amplified by PCR using primers ITS1 (5'-TCCGTAGGTGAACCTGCGG-3') and ITS4 (5'-TCCTCCGCTTATTGATATGC-3'). The PCR mixture consisted of $12.5 \mu \mathrm{L}$ Taq premix (TaKaRa, Beijing, China), $0.25 \mu \mathrm{L}(10 \mu \mathrm{M})$ of each primer, $0.75 \mu \mathrm{L}$ dimethyl sulfoxide (DMSO), $10.25 \mu \mathrm{L} \mathrm{dd} \mathrm{H}_{2} \mathrm{O}$, and $1 \mu \mathrm{L}$ DNA template. After denaturation at $95^{\circ} \mathrm{C}$ for $4 \mathrm{~min}$, amplification was performed with 32 cycles of $30 \mathrm{~s}$ at $95^{\circ} \mathrm{C}, 30 \mathrm{~s}$ at $55^{\circ} \mathrm{C}$, and $40 \mathrm{~s}$ at $72{ }^{\circ} \mathrm{C}$, 
and a final extension at $72{ }^{\circ} \mathrm{C}$ for $7 \mathrm{~min}$. The ITS1-5.8S-ITS2 rDNA sequence of the fungus has been submitted to GenBank with the accession number MF716581. A voucher specimen was deposited at the Third Institute of Oceanography, SOA, China. The working strain was prepared on potato dextrose agar slants and stored at $4^{\circ} \mathrm{C}$.

\subsection{Fermentation, Extraction, and Isolation}

Strain SP2-8-1 was cultured on PDA plates at $28{ }^{\circ} \mathrm{C}$ for 3 days. Then, six plugs $(5 \mathrm{~mm}$ diameter) were transferred to 12 Erlenmeyer flasks (1 L), each containing $500 \mathrm{~mL}$ Czapek's medium (sucrose $30 \mathrm{~g} / \mathrm{L}, \mathrm{NaNO}_{3} 3.0 \mathrm{~g} / \mathrm{L}, \mathrm{MgSO}_{4} \cdot 7 \mathrm{H}_{2} \mathrm{O} 0.5 \mathrm{~g} / \mathrm{L}, \mathrm{KH}_{2} \mathrm{PO} 41.0 \mathrm{~g} / \mathrm{L}, \mathrm{FeSO}_{4} 0.01 \mathrm{~g} / \mathrm{L}$ and $\mathrm{KCl}$ $0.5 \mathrm{~g} / \mathrm{L})$ in sterile conditions. Erlenmeyer flasks were shaken on a rotary shaker at $28^{\circ} \mathrm{C}$ and $120 \mathrm{rpm}$ for 3 days to form seed cultures $\left(1 \times 10^{8}\right.$ spores $\left./ \mathrm{mL}\right)$. Next, seed cultures $(40 \times 100 \mathrm{~mL})$ were transferred to flasks $(40 \times 1 \mathrm{~L})$ containing $45 \mathrm{~g}$ of millet and $105 \mathrm{~g}$ of rice per flask. After 28 days, the fermented culture was dried, smashed, and extracted with ethyl acetate (EtOAc). The EtOAc extract $(220 \mathrm{~g})$ was partitioned between petroleum ether (PE) and $\mathrm{H}_{2} \mathrm{O}$, and then between EtOAc and $\mathrm{H}_{2} \mathrm{O}$. Removal of the solvent of the EtOAc extract gave $150 \mathrm{~g}$ of residue, which was subject to silica gel (200-300 mesh) column chromatography, eluting with PE-EtOAC (9:1, 8.5:1.5, 8:2, 7.5:2.5, 6:4, $5: 5,4: 6, V: V)$ to yield seven fractions, A-G. Further separation of fraction B $(8.5: 1.5,24 \mathrm{~g})$ was applied to silica gel column chromatography using PE-acetone and semi-preparative HPLC (80\% methanol in $\mathrm{H}_{2} \mathrm{O}$, flow rate $\left.12 \mathrm{~mL} / \mathrm{min}\right)$ to give compounds $15(16 \mathrm{mg}), 18(16 \mathrm{mg})$ and $16(16 \mathrm{mg})$. Fraction C $(8: 2,15 \mathrm{~g})$ was further purified by semi-preparative HPLC ( $60 \%$ methanol in $\mathrm{H}_{2} \mathrm{O}$, flow rate $\left.8 \mathrm{~mL} / \mathrm{min}\right)$ and Sephadex LH-20 (50\% chloroform in methanol) to give compounds 17 (16 mg) and 2 (4.5 mg). Fraction D (7.5:2.5, $10 \mathrm{~g})$ was further purified by silica gel (200-300 mesh) column chromatography, eluting with hexane-EtOAc $(6: 4, V: V)$ and Sephadex LH-20 (methanol) to obtain compounds 3 (3.8 mg), 1 (32 mg) and 5 (16.9 mg). Fraction E (6:4, $10 \mathrm{~g})$ was further separated by semi-preparative HPLC (80\% methanol in $\mathrm{H}_{2} \mathrm{O}$, flow rate $8 \mathrm{~mL} / \mathrm{min}$ ), Sephadex $\mathrm{LH}-20$ (85\% methanol in $\mathrm{H}_{2} \mathrm{O}$ ), and preparative TLC to obtain compounds $4(12 \mathrm{mg}), 6(15 \mathrm{mg})$, and $7(20 \mathrm{mg})$. Fraction F (5:5, $20 \mathrm{~g})$ was further separated by semi-preparative HPLC ( $80 \%$ methanol in $\mathrm{H}_{2} \mathrm{O}$, flow rate $\left.8 \mathrm{~mL} / \mathrm{min}\right)$ and Sephadex LH-20 (methanol) to obtain compounds 8 (24 mg), 9 (15 mg), and 12 (25 mg). Fraction G (4:6, $32 \mathrm{~g})$ was further separated by semi-preparative HPLC ( $80 \%$ methanol in $\mathrm{H}_{2} \mathrm{O}$, flow rate $\left.8 \mathrm{~mL} / \mathrm{min}\right)$ and Sephadex LH-20 (methanol) to obtain compounds 11 (120 mg), 10 (60 mg), 13 (20 mg), and 14 (15 mg).

4-methyl-candidusin A (1): colorless amorphous solid; UV $\lambda_{\max }$ (methanol) $\mathrm{nm}(\log \varepsilon): 295$ (4.19); ${ }^{1} \mathrm{H}$ NMR and ${ }^{13} \mathrm{C}$ NMR data are shown in Table 1 ; HR-ESI-MS: $m / z$ 367.11757 $[\mathrm{M}+\mathrm{H}]^{+}$(Calcd. for 367.11816, $\left.\mathrm{C}_{21} \mathrm{H}_{19} \mathrm{O}_{6}\right)$.

Aspetritone A (2): yellow amorphous solid; $[\alpha]_{D}^{20.0}-350(c 0.15, \mathrm{MeOH})$; UV $\lambda_{\max }$ (methanol) $\mathrm{nm}$ $(\log \varepsilon): 257$ (3.58); ${ }^{1} \mathrm{H}$ NMR and ${ }^{13} \mathrm{C}$ NMR data are shown in Table 1; HR-ESI-MS: $m / z 333.0966$ $[\mathrm{M}-\mathrm{H}]^{-}$(Calcd. for 333.0974, $\left.\mathrm{C}_{17} \mathrm{H}_{17} \mathrm{O}_{7}\right)$.

Aspetritone B (3): yellow amorphous solid; $[\alpha]_{D}^{20.0}-156$ (c 0.6, MeOH); UV $\lambda_{\max }(\operatorname{methanol}) \mathrm{nm}(\log \varepsilon)$ : 265 (3.73); 283 (3.53); ${ }^{1} \mathrm{H}$ NMR and ${ }^{13} \mathrm{C}$ NMR data are shown in Table 1; HR-ESI-MS: $m / z 333.0979$ $[\mathrm{M}-\mathrm{H}]^{-}$(Calcd. for 333.0974, $\mathrm{C}_{17} \mathrm{H}_{17} \mathrm{O}_{7}$ ).

\subsection{Antibacterial Assay}

Antibacterial activities against MRSA (ATCC 43300, CGMCC 1.12409), V. rotiferianus (MCCC E385), V. vulnificus (MCCC E1758), and V. campbellii (MCCC E333) were tested by continuous dilution in 96-well plates using resazurin as a surrogate indicator. Blue resazurin was reduced by metabolically active bacteria to pink resorufin. A mid-logarithmic-phase tested strain was added at a starting inoculum of $5 \times 10^{5} \mathrm{CFU} / \mathrm{mL}$ to the plate containing tested compound (final concentration ranging from 250 to $0.98 \mu \mathrm{g} / \mathrm{mL}$ in two-fold dilution) plus $10 \%$ resazurin solution $(6.75 \mathrm{mg} / \mathrm{mL}$ in sterile water). The foil covered plate was incubated for $24 \mathrm{~h}$ with shaking at $37^{\circ} \mathrm{C}$. After that, by observing the 
blue-to-pink color change, the MIC value was determined to be the lowest concentration that did not induce the color change [18-20].

\subsection{Cytotoxicity Assay}

Hela (cervical cancer cell), Hep G2 (human liver cancer cell), and A549 (adenocarcinomic human alveolar basal epithelial cell) cells were maintained in DMEM, MEM, and F-12K medium respectively, and supplied with $10 \% \mathrm{FBS}, 100 \mathrm{U} / \mathrm{mL}$ of penicillin, and $100 \mathrm{mg} / \mathrm{mL}$ of streptomycin [21]. Cells were grown in a humidified chamber with $5 \% \mathrm{CO}_{2}$ at $37{ }^{\circ} \mathrm{C}$. For cytotoxicity assays, cells were seeded at a density of 5000 cells per well in 96-well plates, grown at $37{ }^{\circ} \mathrm{C}$ for $12 \mathrm{~h}$, and then treated with tested compound at five different concentrations $(100 \mu \mathrm{L}$ medium/well). The cytotoxicity was measured by Cell Counting Kit-8 (CCK-8) (DOJINDO) at $48 \mathrm{~h}$ post-treatment, following the manufacturer's instructions.

CCK-8 assay is based on the conversion of a tetrazolium salt, 2-(2-methoxy-4-nitrophenyl)-3(4-nitrophenyl)-5-(2,4-disulfophenyl)-2H-tetrazolium, monosodium salt (WST-8), and a water-soluble formazan dye, upon reduction by dehydrogenases in the presence of an electronmediator [22]. WST-8 is reduced by dehydrogenases in cells to give an orange colored product (formazan). The amount of the formazan dye is directly proportional to the number of living cells.

In brief, $10 \mu \mathrm{L}$ of CCK-8 solution was added to each well of the 96-well plates. After incubation at $37^{\circ} \mathrm{C}$ for $2 \mathrm{~h}$, the absorbance at $450 \mathrm{~nm}$ was measured using a SpectraMAX M5 microplate reader. Wells with only culture medium and CCK-8 solution were used to determine the background, and cells treated with DMSO were included as the negative controls [21].

\subsection{ECD Calculation}

Conformational analysis was initially performed using Confab [23] with the MMFF94 force field for all configurations. Room-temperature equilibrium populations were calculated according to the Boltzmann distribution law Equation (1). The conformers with Boltzmann-populations of over 1\% were chosen for ECD calculations. The energies and populations of all dominative conformers were provided in Table S1.

$$
\frac{N_{i}}{N}=\frac{g_{i} e^{-\frac{E_{i}}{k_{\mathrm{B}} T}}}{\sum g_{i} e^{-\frac{E_{i}}{k_{\mathrm{B}} T}}}
$$

$N_{i}$ is the number of conformer $i$ with energy $E_{i}$ and degeneracy $g_{i}$ at temperature $T$, and $k_{\mathrm{B}}$ is the Boltzmann constant.

The theoretical calculation was carried out using Gaussian 09. First, the chosen conformer was optimized at PM6 using the semi-empirical theory method, and then optimized at B3LYP/6-311G** in methanol using the conductor-like polarizable continuum model (CPCM) (Table S2). The theoretical calculation of ECD was conducted in methanol using TD-DFT at the same theory level. Rotatory strengths for a total of 50 excited states were calculated. The ECD spectrum is simulated in SpecDis [24] by overlapping Gaussian functions for each transition.

\section{Conclusions}

In current research, we have isolated three novel compounds, 4-methyl candidusin A (1), aspetritone A (2), and aspetritone B (3), together with two prenylcandidusin derivatives (4-5), two candidusin derivatives (6-7), seven terphenyllin derivatives (8-14), and four anthraquinone derivatives (15-18). Candidusin can be deduced to be a cyclization product of terphenyllin between C- 6 and C-2' via an oxygen atom. C-prenylation plays an important role in diversification of natural compounds, especially for flavonoids and coumarins [25]. These compounds exhibit significant in vitro biological activities (cytotoxic, antibacterial, osteogenic, antioxidant, and anti-inflammatory activities) [25]. Prenylation in polyhydroxy-p-terphenyl analogues, as 3,4-dimethyl-3"-prenylcandidusin A (4), 4-methyl-3"-prenylcandidusin A (5), 
3-prenylterphenyllin (10), and 3"-prenylterphenyllin (14), described in this paper, preliminarily influences the cytotoxicity and antibacterial activities, compared to the un-prenylated terphenyllin and candidusin derivatives. Chemical structures of compounds $\mathbf{2 , 3}$, and 15-18 also preliminarily indicate that the special tetrahydrobenzene moiety located in compounds 2 and 3 attributed to their relatively strong bioactivity. Therefore, isolation or synthesis of more prenylated-terphenyllin, prenylated-candidusin, and tetrahydroanthraquinone derivatives deserves attention as an important aspect of structure-activity relationship studies.

Supplementary Materials: The following are available online at www.mdpi.com/1660-3397/15/11/348/s1: NMR spectra for compounds 1-3 as well as computational data for compounds 1-2.

Acknowledgments: This research was supported by the International Science \& Technology Cooperation Program of China [2015DFA20500]. We would like to thank all of the members of Peng Cai's group in the Institute of Urban Environment, Chinese Academy of Sciences, as well as Wei Xu in the Third institute of Oceanography, $\mathrm{SOA}$, for their assistance in this work.

Author Contributions: Weiyi Wang carried out the isolation and structural elucidation, and wrote this paper. Yanyan Liao performed the antibacterial and cytotoxic activity evaluations. Chao Tang and Xiaomei Huang carried out the fermentation of fungi. Zhuhua Luo contributed to this work by ITS sequencing. Jianming Chen and Peng Cai conceived and designed the experiments. Peng Cai contributed to the revision of the paper.

Conflicts of Interest: The authors declare no conflict of interest.

\section{References}

1. Fouillaud, M.; Venkatachalam, M.; Girard-Valenciennes, E.; Caro, Y.; Dufosse, L. Anthraquinones and derivatives from marine-derived fungi: Structural diversity and selected biological activities. Mar. Drugs 2016, 14, 64. [CrossRef] [PubMed]

2. Schueffler, A.; Anke, T. Fungal natural products in research and development. Nat. Prod. Rep. 2014, 31, 1425-1448. [CrossRef] [PubMed]

3. Cai, S.; Sun, S.; Zhou, H.; Kong, X.; Zhu, T.; Li, D.; Gu, Q. Prenylated polyhydroxy-p-terphenyls from Aspergillus taichungensis ZHN-7-07. J. Nat. Prod. 2011, 74, 1106-1110. [CrossRef] [PubMed]

4. Liu, S.S.; Zhao, B.B.; Lu, C.H.; Huang, J.J.; Shen, Y.M. Two new p-terphenyl derivatives from the marine fungal strain Aspergillus sp. AF119. Nat. Prod. Commun. 2012, 7, 1057-1062. Available online: https://www.ncbi.nlm.nih.gov/pubmed/22978228 (accessed on 1 August 2012). [PubMed]

5. Xu, J.; Nakazawa, T.; Ukai, K.; Kobayashi, H.; Mangindaan, R.E.P.; Wewengkang, D.S.; Rotinsulu, H.; Namikoshi, M. Tetrahydrobostrycin and 1-Deoxytetrahydrobostrycin, Two New Hexahydroanthrone Derivatives, from a Marine-derived Fungus Aspergillus sp. J. Antibiot. 2008, 61, 415-419. [CrossRef] [PubMed]

6. Chen, H.; Zhong, L.; Long, Y.; Li, J.; Wu, J.; Liu, L.; Chen, S.; Lin, Y.; Li, M.; Zhu, X.; et al. Studies on the synthesis of derivatives of marine-derived bostrycin and their structure-activity relationship against tumor cells. Mar. Drugs 2012, 10, 932-952. [CrossRef] [PubMed]

7. Wang, C.; Ding, X.; Feng, S.X.; Guan, Q.; Zhang, X.P.; Du, C.; Di, Y.T.; Chen, T. Seven new tetrahydroanthraquinones from the root of Prismatomeris connata and their cytotoxicity against lung tumor cell growth. Molecules 2015, 20, 22565-22577. [CrossRef] [PubMed]

8. Ondeyka, J.; Buevich, A.V.; Williamson, R.T.; Zink, D.L.; Polishook, J.D.; Occi, J.; Vicente, F.; Basilio, A.; Bills, G.F.; Donald, R.G.; et al. Isolation, structure elucidation, and biological activity of altersolanol P using Staphylococcus aureus fitness test based genome-wide screening. J. Nat. Prod. 2014, 77, 497-502. [CrossRef] [PubMed]

9. Debbab, A.; Aly, A.H.; Edrada-Ebel, R.; Wray, V.; Muller, W.E.; Totzke, F.; Zirrgiebel, U.; Schachtele, C.; Kubbutat, M.H.; Lin, W.H.; et al. Bioactive metabolites from the endophytic fungus Stemphylium globuliferum isolated from Mentha pulegium. J. Nat. Prod. 2009, 72, 626-631. [CrossRef] [PubMed]

10. Guo, Z.K.; Yan, T.; Guo, Y.; Song, Y.C.; Jiao, R.H.; Tan, R.X.; Ge, H.M. P-Terphenyl and diterpenoid metabolites from endophytic Aspergillus sp. YXf3. J. Nat. Prod. 2012, 75, 15-21. [CrossRef] [PubMed]

11. Huang, H.; Feng, X.; Xiao, Z.; Liu, L.; Li, H.; Ma, L.; Lu, Y.; Ju, J.; She, Z.; Lin, Y. Azaphilones and p-terphenyls from the mangrove endophytic fungus Penicillium chermesinum (ZH4-E2) isolated from the South China Sea. J. Nat. Prod. 2011, 74, 997-1002. [CrossRef] [PubMed] 
12. Marchelli, R.; Vining, L.C. Terphenyllin, A novel p-terphenyl metabolite from Aspergillus candidus. J. Antibiot. (Tokyo) 1975, 28, 328-331. [CrossRef] [PubMed]

13. Kurobane, I.; Vining, L.C.; McInnes, A.G.; Smith, D.G. 3-Hydroxyterphenyllin, a new metabolite of Aspergillus candidus Structure elucidation by $\mathrm{H}$ and $\mathrm{C}$ nuclear magnetic resonance spectroscopy. J. Antibiot. (Tokyo) 1979, 32, 559-564. [CrossRef] [PubMed]

14. Kamigauchi, T.; Sakazaki, R.; Nagashima, K.; Kawamura, Y.; Yasuda, Y.; Matsushima, K.; Tani, H.; Takahashi, Y.; Ishii, K.; Suzuki, R.; et al. Terprenins, Novel immunosuppressants produced by Aspergillus candidus. J. Antibiot. (Tokyo) 1998, 51, 445-450. [CrossRef]

15. Zhang, W.; Wei, W.; Shi, J.; Chen, C.; Zhao, G.; Jiao, R.; Tan, R. Natural phenolic metabolites from endophytic Aspergillus sp. IFB-YXS with antimicrobial activity. BioOrg. Med. Chem. Lett. 2015, 25, 2698-2701. [CrossRef] [PubMed]

16. Feng, S.-X.; Hao, J.; Chen, T.; Qiu, S.X. A New Anthraquinone and two new tetrahydroanthraquinones from the Roots of Prismatomeris connata. Helv. Chim. Acta 2011, 94, 1843-1849. [CrossRef]

17. Lai, X.; Cao, L.; Tan, H.; Fang, S.; Huang, Y.; Zhou, S. Fungal communities from methane hydrate-bearing deep-sea marine sediments in South China Sea. ISME J. 2007, 1, 756-762. [CrossRef] [PubMed]

18. Chhillar, A.K.; Gahlaut, A. Evaluation of antibacterial potential of plant extracts using resazurin based microtiter dilution assay. Int. J. Pharm. Pharm. Sci. 2013, 5, 372-376.

19. Wibowo, A.; Ahmat, N.; Hamzah, A.S.; Low, A.L.; Mohamad, S.A.; Khong, H.Y.; Sufian, A.S.; Manshoor, N.; Takayama, H.; Malaysianol, B. An oligostilbenoid derivative from Dryobalanops lanceolata. Fitoterapia 2012, 83, 1569-1575. [CrossRef] [PubMed]

20. Coban, A.Y. Rapid determination of methicillin resistance among Staphylococcus aureus clinical isolates by colorimetric methods. J. Clin. Microbiol. 2012, 50, 2191-2193. [CrossRef] [PubMed]

21. Han, S.B.; Shin, Y.J.; Hyon, J.Y.; Wee, W.R. Cytotoxicity of voriconazole on cultured human corneal endothelial cells. Antimicrob. Agents. Chemother. 2011, 55, 4519-4523. [CrossRef] [PubMed]

22. Ishiyama, M.; Tominaga, H.; Shiga, M.; Sasamoto, K.; Ohkura, Y.; Ueno, K. A combined assay of cell viability and in vitro cytotoxicity with a highly water-soluble tetrazolium salt, neutral red and crystal violet. Biol. Pharm. Bull. 1996, 19, 1518-1520. [CrossRef] [PubMed]

23. O’Boyle, N.M.; Vandermeersch, T.; Flynn, C.J.; Maguire, A.R.; Hutchison, G.R. Confab-Systematic generation of diverse low-energy conformers. J. Cheminform. 2011, 3, 8. [CrossRef] [PubMed]

24. Bruhn, T.; Schaumloffel, A.; Hemberger, Y.; Bringmann, G. SpecDis: Quantifying the comparison of calculated and experimental electronic circular dichroism spectra. Chirality 2013, 25, 243-249. [CrossRef] [PubMed]

25. Chen, X.; Mukwaya, E.; Wong, M.S.; Zhang, Y. A systematic review on biological activities of prenylated flavonoids. Pharm. Biol. 2014, 52, 655-660. [CrossRef] [PubMed] 